\begin{tabular}{|c|l|}
\hline Title & $\begin{array}{l}\text { Puumala virus infection in Syrian hamsters (Mesocricetus auratus) resembling hantavirus infection in natural rodent } \\
\text { hosts }\end{array}$ \\
\hline Author(s) & $\begin{array}{l}\text { Sanada, Takahiro; Kariwa, Hiroaki; Nagata, Noriyo; Tanikawa, Y oichi; Seto, T akahiro; Y oshimatsu, Kumiko; A rikawa, } \\
\text { Jiro; Yoshi, Kentaro; Takashima, Ikuo }\end{array}$ \\
\hline Citation & $\begin{array}{l}\text { Virus Research, 160(1-2), 108119 } \\
\text { https://doi.org/10.1016/.virusres.2011.05.021 }\end{array}$ \\
\hline Issue Date & 2011-09 \\
\hline Doc URL & http://hdl.handle.net/2115/47378 \\
\hline Type & article(author version) \\
\hline File Information & VR160-1-2_108-119.pdf \\
\hline
\end{tabular}

Instructions for use 


\section{Puumala virus infection in Syrian hamsters (Mesocricetus auratus) resembling hantavirus infection in natural rodent hosts}

\section{Author names and affiliations}

Takahiro Sanada $^{\mathrm{a}}$, Hiroaki Kariwa ${ }^{\mathrm{a}}$, Noriyo Nagata ${ }^{\mathrm{b}}$, Yoichi Tanikawa ${ }^{\mathrm{a}}$, Takahiro Seto ${ }^{\mathrm{a}}$, Kumiko Yoshimatsu ${ }^{\mathrm{c}}$, Jiro Arikawa ${ }^{\mathrm{c}}$, Kentaro Yoshii ${ }^{\mathrm{a}}$, Ikuo Takashima ${ }^{\mathrm{a}}$

${ }^{a}$ Graduate School of Veterinary Medicine, Hokkaido University, Sapporo, Hokkaido 060-0818, Japan

${ }^{b}$ Department of Pathology, National Institute of Infectious Diseases, Tokyo 208-0011, Japan

${ }^{c}$ Graduate School of Medicine, Hokkaido University, Sapporo, Hokkaido 060-0838, Japan

\section{Corresponding author}

Hiroaki Kariwa

Graduate School of Veterinary Medicine, Hokkaido University, Kita-18 Nishi-9, Kita-ku, Sapporo, Hokkaido 060-0818, Japan

e-mail: kariwa@vetmed.hokudai.ac.jp

Tel: $+81-11-706-5212$

Fax: +81-11-706-5212 


\begin{abstract}
The mechanism of hantavirus persistent infection in natural hosts is poorly understood due to a lack of laboratory animal models. Herein, we report that Syrian hamsters (Mesocricetus auratus) infected with Puumala virus (PUUV) at 4 weeks old show persistent infection without clinical symptoms for more than 2 months. IgG and IgM antibodies against the viral nucleocapsid protein and neutralizing antibody were first detectable at 14 days postinoculation (dpi) and maintained through 70 dpi. Viral RNA was first detected from 3 dpi in lungs and blood clots, and was detected in all tissues tested at 7 dpi. The viral RNA persisted for at least 70 days in the lungs, kidney, spleen, heart, and brain. The highest level of RNA copies was observed at 14 dpi in the lungs. Slight inflammatory reactions were observed in the lungs, adrenal glands, and brain. Immunohistochemical analysis revealed that PUUV antigen persisted until 56 dpi in the kidneys and adrenal glands. Infected hamsters showed no body weight loss or clinical signs. These results indicate that PUUV infection in hamsters is quite similar to the hantavirus infection of natural host rodents.
\end{abstract}

\title{
Keywords
}

Hantavirus; Puumala virus; Animal model; Persistent infection; Hamster 


\section{Introduction}

Hantaviruses, which belong to the family Bunyaviridae, are distributed worldwide and carried by a variety of rodent and insectivore species (Jonsson et al., 2010). Hantaviruses possess a trisegmented, negative-stranded RNA genome consisting of small (S), medium (M), and large (L) segments (Plyusnin et al., 1996), which encode nucleocapsid proteins (N), envelope glycoproteins ( $\mathrm{Gn}$ and $\mathrm{Gc}$ ), and RNA-dependent RNA polymerase, respectively (Plyusnin et al., 1996). Hantaviruses cause two human diseases: hemorrhagic fever with renal syndrome (HFRS) and hantavirus cardiopulmonary syndrome (HCPS) (Jonsson et al., 2010). The clinical symptoms of HFRS are characterized by fever, renal failure, and hemorrhage with capillary leakage (Muranyi et al., 2005). HFRS occurs mainly in Asia and Europe, with 150,000-200,000 cases annually (Jonsson et al., 2010; Muranyi et al., 2005), and its case fatality rate is $0.1 \%-15 \%$ (Kanerva et al., 1998; Muranyi et al., 2005). Hantaan virus (HTNV), Seoul virus (SEOV), Amur virus (AMRV), Dobrava-Belgrade virus (DOBV), Saaremaa virus (SAAV), and Puumala virus (PUUV) have been identified as etiologic agents of HFRS, and they are each carried by a specific rodent species: striped field mouse, Apodemus agrarius; Norway rat, Rattus norvegicus; Korean field mouse, Apodemus peninsulae; yellow necked mouse, Apodemus flavicollis; striped field mouse, Apodemus agrarius; and bank vole, Myodes glareolus, respectively (Jonsson et al., 2010). HCPS is characterized by fever and severe cardiopulmonary dysfunction (Muranyi et al., 2005). Sin Nombre virus (SNV), Laguna Negra virus (LNV), and Andes virus (ANDV) are considered to be the major pathogens of HCPS (Bi et al., 2008; Jonsson et al., 2010). The case fatality rate of HCPS is as much as 50\% (Muranyi et al., 2005).

In contrast to human infections, hantaviruses are generally believed to infect natural hosts persistently and are nonpathogenic to their reservoir hosts (Gavrilovskaya et al., 1990; Yanagihara et al., 1985). Although an immune response to the virus is induced, the natural 
hosts harbor viral RNA and antigens, especially in the lungs, and maintain the virus for over a year after infection (Gavrilovskaya et al., 1990; Lee et al., 1981; Yanagihara et al., 1985). The virus is shed in rodent excreta, such as urine, feces, and saliva, which are believed to represent the major source of hantavirus infection in humans by inhalation (Lee et al., 1981; Vapalahti et al., 2003; Yanagihara et al., 1985).

The mechanisms for persistent infection of hantaviruses in their natural hosts remain unclear. One factor that impedes the clarification of these mechanisms is a lack of animal models. To date, no laboratory animal model is persistently infected with hantavirus that shows no clinical signs as natural hosts. Some researchers have used colonized wild rodents for analyzing the kinetics of hantavirus in natural hosts (Botten et al., 2000; Gavrilovskaya et al., 1990; Hardestam et al., 2008; Lee et al., 1981; Yanagihara et al., 1985), but four major problems exist associated with the use of wild rodents species in laboratory experiments. First, wild rodents should be handled and bred with specialized technical skill. Second, wild rodents have a diverse genetic background. Third, microbiological control is difficult in wild rodents because they are potential carriers of various microbes. And fourth, few research tools are available to analyze wild rodents. Therefore, developing animal models of hantavirus persistent infection is necessary using common laboratory animals.

In this study, we report that Syrian hamsters infected at 4 weeks old with PUUV, which is the etiologic agent of HFRS, showed persistent infection. Despite a high level of antibodies against PUUV, the animals harbored high levels of viral RNA in the acute phase of infection and maintained the virus in lungs for 70 days postinoculation (dpi). Viral RNA and antigens were also detected in some organs, but the hamsters showed no signs of illness. These data suggest that the Syrian hamster could be a suitable animal model resembling hantavirus persistent infection in the natural host. 


\section{Materials and Methods}

\subsection{Cells and virus}

The Sotkamo strain of PUUV was propagated in Vero E6 cells. Cells were cultivated in Eagle's minimum essential medium (EMEM) supplemented with 10\% fetal bovine serum, 2 $\mathrm{mM} \mathrm{L}$-glutamine, $100 \mathrm{IU} / \mathrm{ml}$ penicillin, and $100 \mu \mathrm{g} / \mathrm{ml}$ streptomycin at $37^{\circ} \mathrm{C}$ in a $5 \% \mathrm{CO}_{2}$ incubator. Following incubation for 14 days, the culture fluid from the cell monolayer was collected as the virus stock and stored at $-80^{\circ} \mathrm{C}$ until use.

\subsection{Animals}

Four-week-old (subadult) and 8-week-old (adult) male Syrian hamsters (SLC Inc., Hamamatsu, Japan) were inoculated subcutaneously with 3,300 focus-forming units (FFU) or EMEM as control. Hamsters were observed daily and their body weight was measured. Two to 3 animals from 4-week-old group were killed on $3,7,14,28,42,55$, or $70 \mathrm{dpi}$, and 3 to 5 animals from 8-week old group were killed on 3, 7, 14, 28, 42, 56, or 70 dpi. Their internal organs (brain, heart, lung, liver, spleen, and kidney) and sera were collected and stored at $-80^{\circ} \mathrm{C}$ until analysis. All animal experiments were performed according to the guidelines of animal experimentation at the School of Veterinary Medicine, Hokkaido University, and carried out at a biosafety level 3 animal facility.

\subsection{Antibody}

The mouse monoclonal antibody E5/G6 against HTNV N and cross-reactive with PUUV N was obtained by immunization with HTNV-infected cell lysate (Yoshimatsu et al., 1996).

\subsection{Indirect immunofluorescent antibody test (IFA)}

The sera were tested for antibodies to PUUV using an IFA method. Vero E6 cells were 
infected with Puumala virus Sotkamo strain and cultured for 21 days. The infected cells were collected by trypsinization and spotted onto 24-well slides. After incubation for $4 \mathrm{~h}$ in a $\mathrm{CO}_{2}$ incubator, the cells were fixed with cold acetone for $20 \mathrm{~min}$ and air-dried. The slides were stored at $-40^{\circ} \mathrm{C}$ until use. Hamster sera were diluted serially by twofold (starting at 1:16) with phosphate-buffered saline (PBS) and spotted onto the slide. After incubation at $37^{\circ} \mathrm{C}$ for $1 \mathrm{~h}$, the slides were washed three times with PBS. Alexa Fluor ${ }^{\circledR} 488$ conjugated anti-hamster IgG (Invitrogen, Carlsbad, CA, U.S.A.) diluted 1:1000 in PBS was spotted on the slides and incubated at $37^{\circ} \mathrm{C}$ for $1 \mathrm{~h}$. The IFA titers of each serum were determined as the reciprocal of the maximum dilution of serum that yielded scattered granular fluorescence in the cytoplasm.

\subsection{IgG detection enzyme-linked immunosorbent assay (IgG-ELISA)}

Recombinant N (rN) of Hokkaido virus (Kariwa et al., 1995) was expressed as a fusion protein with N-utilization substance A (NusA) by cloning into the pET-43.1c(+) vector (Novagen, San Diego, CA, U.S.A.) and purified using the ProBond ${ }^{\mathrm{TM}}$ purification system (Invitrogen). Then 96-well EIA/RIA plates (Corning Inc., Corning, NY, U.S.A.) were coated overnight at $4{ }^{\circ} \mathrm{C}$ with $50 \mu \mathrm{l}$ per well of the $\mathrm{rN}$ or the NusA diluted in PBS at a concentration of $1.6 \mu \mathrm{g} / \mathrm{ml}$. The coated plates were blocked with $200 \mu \mathrm{l}$ per well of $3 \%$ bovine serum albumin (BSA) in $\mathrm{PBS}$ at $37^{\circ} \mathrm{C}$ for $1 \mathrm{~h}$, followed by washing three times with PBS containing $0.5 \%$ Tween 20 (PBST); then $50 \mu$ of the serum samples diluted to 1:200 in PBST were added to the plates. Each serum sample was reacted with the rN and the NusA protein. After $1 \mathrm{~h}$ of incubation at $37^{\circ} \mathrm{C}$, the plates were washed three times with PBST. The plates were then incubated with $50 \mu \mathrm{l}$ of peroxidase conjugated anti-hamster IgG diluted to $1: 1,000$ in PBST at $37^{\circ} \mathrm{C}$ for $1 \mathrm{~h}$. After washing, $100 \mu \mathrm{l}$ of $o$-phenylenediamine substrate with hydrogen peroxide was added to each well, and the plates were incubated at $37^{\circ} \mathrm{C}$ for $30 \mathrm{~min}$. The absorbance was then measured at $450 \mathrm{~nm}$ and the value for each sample in the well with 
NusA was subtracted from that of the corresponding well containing rN.

\subsection{Preparation of antigens for IgM detection ELISA (IgM- ELISA) and N detection ELISA} (N-ELISA)

Monolayers of Vero E6 cells were infected with the Sotkamo strain of PUUV and incubated for 14 days. After centrifugation at $100 \times g$ for $2 \mathrm{~min}$, the cells were resuspended in lysis buffer (0.01 M Tris-HCl, 2\% Triton X-100, 0.15 M NaCl, 0.6 M KCl, 5 mM EDTA) to $2 \times 10^{7}$ cells $/ \mathrm{ml}$. The lysates were centrifuged at $16,000 \times g$ for $15 \mathrm{~min}$. The supernatants were collected and used for IgM-detection ELISA.

Lungs were mixed with lysis buffer and homogenized by shaking with a zirconium bead at 30 times per second for 3 min using a mixer mill (MM300; Retsch, Haan, Germany). The homogenates were kept on ice for $30 \mathrm{~min}$ and centrifuged at $6,000 \times g$ for $10 \mathrm{~min}$. Supernatants were collected and used for viral antigen detection.

\subsection{IgM-ELISA}

Plates were coated with $50 \mu \mathrm{l}$ of rabbit IgG against hamster $\operatorname{IgM} \mu$ chain (diluted to 25 $\mu \mathrm{g} / \mathrm{ml}$ in PBS; Rockland Immunochemicals, Gilbertsville, PA, U.S.A.) at $4^{\circ} \mathrm{C}$ overnight. The plates were blocked with $200 \mu \mathrm{l}$ of $3 \% \mathrm{BSA}$ in PBS at $37^{\circ} \mathrm{C}$ for $1 \mathrm{~h}$. The plates were washed three times with PBST, and $50 \mu \mathrm{l}$ of each serum sample diluted to 1:100 was added and incubated at $37^{\circ} \mathrm{C}$ for $1 \mathrm{~h}$. After washing, $50 \mu$ of each cell lysate diluted to $1: 10$ with PBST was added to each well. The plates were then incubated at $37^{\circ} \mathrm{C}$ for $1 \mathrm{~h}$ and washed. The biotinylated monoclonal antibody E5/G6 diluted to $1 \mu \mathrm{g} / \mathrm{ml}$ with PBST was added and incubated at $37^{\circ} \mathrm{C}$ for $1 \mathrm{~h}$. The plates were then washed, and $50 \mu \mathrm{l}$ of peroxidase conjugated NeutrAvidin ${ }^{\mathrm{TM}}$ (Pierce Biotechnology, Inc., Rockford, IL, U.S.A.) diluted to $1 \mu \mathrm{g} / \mathrm{ml}$ with PBST was added. After $1 \mathrm{~h}$ of incubation at $37^{\circ} \mathrm{C}$ followed by washing, $100 \mu \mathrm{l}$ of 
o-phenylenediamine substrate with hydrogen peroxide was added, and the plates were incubated at $37^{\circ} \mathrm{C}$ for $30 \mathrm{~min}$. The absorbance was measured at $450 \mathrm{~nm}$, and the value for each serum sample was calculated by subtracting the absorbance of the well with uninfected Vero E6 cell lysate from that of the corresponding well with PUUV-infected cell lysate.

\subsection{Focus reduction neutralization test (FRNT)}

The neutralizing antibody was assessed by a focus reduction neutralization test. Heat-inactivated $\left(56^{\circ} \mathrm{C}, 30 \mathrm{~min}\right)$ serum samples from PUUV-infected hamsters were serially diluted in EMEM and then mixed with an equal volume of EMEM containing approximately $100 \mathrm{FFU}$ of PUUV. This mixture was incubated at $37^{\circ} \mathrm{C}$ for $1 \mathrm{~h}$, and then $50 \mu \mathrm{l}$ of the mixture was added to confluent Vero E6 cells grown in 96-well plates. After $1 \mathrm{~h}$ of incubation at $37^{\circ} \mathrm{C}$, the mixture was removed and the cells were overlaid with EMEM containing $1.5 \%$ carboxymethyl cellulose. After incubation at $37^{\circ} \mathrm{C}$ for 10 days, the overlay medium was removed and cells were washed with PBS. The cells were then fixed with methanol for 15 min at room temperature. The viral foci were stained with E5/G6 $(0.5 \mu \mathrm{g} / \mathrm{ml})$ and Alexa Fluor $^{\circledR}$ 555-conjugated anti-mouse $\operatorname{IgG}(1: 1000$; Invitrogen). The neutralizing antibody titer of each serum sample was determined as the reciprocal of the maximum dilution of the serum that reduced the number of foci by $80 \%$ or more as compared to the control samples.

\subsection{N-ELISA}

The 96-well plates were coated with $50 \mu \mathrm{l}$ per well of MAb E5/G6 diluted to $2 \mu \mathrm{g} / \mathrm{ml}$ in PBS. After overnight incubation at $4^{\circ} \mathrm{C}, 200 \mu 1$ of $3 \%$ BSA in PBS was added for blocking; the plates were incubated at $37^{\circ} \mathrm{C}$ for $1 \mathrm{~h}$ and then washed. After the addition of $50 \mu \mathrm{l}$ of lung homogenates to each well, the plates were incubated at $37^{\circ} \mathrm{C}$ for $1 \mathrm{~h}$. After washing the plates, $50 \mu \mathrm{l}$ the biotinylated MAb E5/G6 diluted to $1 \mu \mathrm{g} / \mathrm{ml}$ with PBST was added to each well. 
After $1 \mathrm{~h}$ of incubation at $37^{\circ} \mathrm{C}$ and washing, $50 \mu$ of peroxidase conjugated NeutrAvidin ${ }^{\mathrm{TM}}$ diluted to $1 \mu \mathrm{g} / \mathrm{ml}$ with PBST was added and incubated at $37^{\circ} \mathrm{C}$ for $1 \mathrm{~h}$. After washing, $100 \mu \mathrm{l}$ of o-phenylenediamine substrate with hydrogen peroxide was added to each well. The plates were incubated at $37^{\circ} \mathrm{C}$ for $30 \mathrm{~min}$ and the absorbance was read at $450 \mathrm{~nm}$.

\subsection{RNA extraction}

Total RNA was extracted from tissues (brain, heart, lung, liver, spleen, and kidney) using ISOGEN (Nippon Gene Co., Ltd., Tokyo, Japan) according to the manufacturer's protocol. Extracted RNA was dissolved in $50 \mu$ of deionized, diethylpyrocarbonate (DEPC)-treated water. RNA was then treated with DNase. The reaction for DNase treatment was carried out in a total volume of $50 \mu \mathrm{l}$ containing $15 \mu \mathrm{g}$ of RNA, $5 \mu \mathrm{l}$ of $10 \times$ DNase buffer, $10 \mathrm{U}$ of DNase I (Takara Bio Inc., Otsu, Japan), and 20 U of RNase Out ribonuclease inhibitor (Invitrogen). The mixtures were incubated at $37^{\circ} \mathrm{C}$ for $30 \mathrm{~min}$. Total RNA was then purified by lithium chloride and dissolved in $30 \mu \mathrm{l}$ of DEPC-treated water.

\subsection{Reverse transcription (RT)}

A $20-\mu \mathrm{l}$ reaction mixture containing $5 \mu \mathrm{g}$ of RNA, $0.75 \mu \mathrm{g}$ of random primers, and 0.5 $\mathrm{mM}$ dNTP was incubated in a thermocycler at $70^{\circ} \mathrm{C}$ for $10 \mathrm{~min}, 25^{\circ} \mathrm{C}$ for $10 \mathrm{~min}$, and chilled on ice for $3 \mathrm{~min}$. After the addition of $10 \mu \mathrm{l}$ of a mixture including $6 \mu \mathrm{l}$ of $5 \times$ first-strand buffer, $10 \mu \mathrm{M}$ DTT, and $200 \mathrm{U}_{\text {of Superscript }}{ }^{\mathrm{TM}}$ II reverse transcriptase (Invitrogen), the reactions were incubated at $42^{\circ} \mathrm{C}$ for $50 \mathrm{~min}$ and heated at $70^{\circ} \mathrm{C}$ for $15 \mathrm{~min}$. Thereafter, the mixture was used as the cDNA sample.

\subsection{Polymerase chain reaction (PCR)}

The S segment of the PUUV genome was amplified by PCR in a $25-\mu 1$ reaction mixture 
containing $1 \mu \mathrm{l}$ of cDNA, $2.5 \mu \mathrm{l}$ of $10 \times$ HIFI buffer, $2 \mathrm{mM} \mathrm{MgSO}_{4}, 0.2 \mathrm{mM} \mathrm{dNTP}, 0.2 \mu \mathrm{M}$ forward primer SotS172Fw (5'-CTG CAA GCC AGG CAA CAA ACA GTG TCA GCA-3'), $0.2 \mu \mathrm{M}$ reverse primer SotS894Rv (5'-GTC TGC CAC ATG ATT TTT GTC AAG CAC ATC-3'), and 1.25 U of Platinum ${ }^{\circledR}$ Taq DNA Polymerase High Fidelity (Invitrogen). Thermal cycling consisted of heating at $94^{\circ} \mathrm{C}$ for 2 min followed by 35 cycles at $94^{\circ} \mathrm{C}$ for $30 \mathrm{~s}, 60^{\circ} \mathrm{C}$ for $30 \mathrm{~s}$, and $68^{\circ} \mathrm{C}$ for $2 \mathrm{~min}$. The amplified products were electrophoresed in a $1 \%$ agarose gel, stained with ethidium bromide, and examined for bands of the appropriate size. Similarly, the PCR products were further amplified using inner primers, SotS269Fw (5'-CTA AAC CTA CTG ACC CGA CTG G-3') and SotS707Rv (5'-GAC CCC CAT AAC TGG ACT CAT-3'). The incubation conditions for the secondary reaction consisted of heating at $94^{\circ} \mathrm{C}$ for 2 min and 35 cycles at $94^{\circ} \mathrm{C}$ for $30 \mathrm{~s}, 57.5^{\circ} \mathrm{C}$ for $30 \mathrm{~s}$, and $68^{\circ} \mathrm{C}$ for $2 \mathrm{~min}$.

\subsection{Quantitative real-time PCR}

Each cDNA sample from various organs of infected hamsters was tested in quadruplicate. Each $25-\mu 1$ reaction mixture contained $2.5 \mu$ of cDNA, $12.5 \mu 1$ of TaqMan ${ }^{\circledR}$ Universal PCR Master Mix (Applied Biosystems, Carlsbad, CA, U.S.A.), $0.9 \mu \mathrm{M}$ forward primer Sotkamo62Fw (5'-TCC AAG AGG ATA TAA CCC GCC AT-3'), $0.9 \mu$ M reverse primer Sotkamo257Rv (5'-TTC CTG GAC ACA GCA TCT GC-3'), and 0.2 $\mu \mathrm{M}$ fluorescent probe Sotkamo194 probe (5'-TGT CAG CAC TGG AGG A-3'). The probe was labeled with the reporter dye, 6-carboxyfluorescein (FAM) at the 5' end, and nonfluorescent quencher and minor groove enhancer (MGB) at the 3' end. PCR cycling conditions consisted of incubations at $50^{\circ} \mathrm{C}$ for $2 \mathrm{~min}$ and $95^{\circ} \mathrm{C}$ for $10 \mathrm{~min}$, followed by 60 cycles at $95^{\circ} \mathrm{C}$ for $15 \mathrm{~s}$ and $60^{\circ} \mathrm{C}$ for 1 $\min$.

Rodent GAPDH mRNA expression was also determined in each sample. Each 25- $\mu \mathrm{l}$ reaction mixture contained $2.5 \mu \mathrm{l}$ of cDNA, $12.5 \mu \mathrm{l}$ of TaqMan ${ }^{\circledR}$ Universal PCR Master Mix, 
$0.1 \mu \mathrm{M}$ rodent GAPDH forward and reverse primers, and $0.2 \mu \mathrm{M}$ rodent GAPDH probe labeled with a VIC dye at the 5' end. The levels of viral genome and GAPDH mRNA were quantified from a standard curve. The results were expressed as the ratio of the copy number of viral RNA to nanograms of GAPDH mRNA.

\subsection{Histopathological and immunohistochemical analysis}

Animals ( $n=2$ per group) were anesthetized and heart, lung, liver, spleen, adrenal gland, kidney, and brain samples were harvested for histopathological investigation. Tissues were fixed with $10 \%$ phosphate-buffered formalin and routinely embedded in paraffin, sectioned, and stained with hematoxylin and eosin. The Vector M.O.M. Immunodetection Kit (Vector Laboratories, Burlingame, CA, U.S.A.) was used for the detection of the PUUV antigens on paraffin-embedded sections. Antigens were retrieved by hydrolytic autoclaving for $10 \mathrm{~min}$ at $121^{\circ} \mathrm{C}$ in $10 \mathrm{mM}$ sodium citrate-sodium chloride buffer ( $\mathrm{pH}$ 6.0). Endogenous peroxidase activity was blocked by incubation in $1 \%$ hydrogen peroxide in methanol for $30 \mathrm{~min}$. The first antibody was the monoclonal antibody E5/G6 $\left(1 \mu \mathrm{g} / \mathrm{ml}\right.$, overnight at $\left.4^{\circ} \mathrm{C}\right)$. 


\section{Results}

\subsection{Body weight and clinical signs}

To investigate whether PUUV causes disease in hamsters, we carefully observed clinical symptoms of the animals daily and measured their body weight. During the observation period, infected hamsters showed no signs of clinical illness or there is no difference between the transition of infected animals and that of uninfected animals (data not shown).

\subsection{Antibody responses}

To investigate the host response to PUUV infection, serum samples were collected at various time points from 3 to $70 \mathrm{dpi}$ and analyzed for the presence of antibodies against PUUV by ELISA, IFA, and FRNT.

The serum levels of IgG and IgM antibodies against the viral $\mathrm{N}$ were measured by ELISA. The IgG antibody was first detectable at $14 \mathrm{dpi}$, peaked at 42 or $56 \mathrm{dpi}$, and maintained until 70 dpi in both 4- and 8-week-old hamsters (Fig. 1A). Little difference was observed between the IgG responses of hamsters inoculated at 4 and 8 weeks of age.

The IgM responses were also first detectable at 14 dpi from the sera of hamsters inoculated at 4 and 8 weeks old (Fig. 1B). The IgM responses of the hamsters inoculated at 4 weeks old increased gradually and were detectable until the end of the observation period, whereas the hamsters inoculated at 8 weeks old maintained $\operatorname{IgM}$ responses at quite a low level.

The results of IFA became positive at 14 dpi in 4- and 8-week-old hamsters, with titers ranging from 1:16 to 1:1024 (Fig. 1C). The IFA titers of hamsters inoculated at 4 weeks old increased greatly and reached the maximum level at $28 \mathrm{dpi}$, with titers ranging from 1:16384 to $1: 32768$. The IFA titers were maintained at the highest level for the next 4 weeks and declined at $70 \mathrm{dpi}$. In contrast, the IFA titers of hamsters inoculated at 8 weeks old reached 
the maximum level at $28 \mathrm{dpi}$ with titers ranging from 1:128 to 1:8192 and were maintained at almost the same level until 70 dpi. The maximal titers of the hamsters inoculated at 8 weeks old were apparently lower level than those of 4-week-old hamsters.

Neutralizing antibodies were produced in both hamsters inoculated at 4 and 8 weeks old (Fig. 1D). In the serum samples of hamsters inoculated at 4 weeks old, the neutralizing antibodies were not detected from 3 to $14 \mathrm{dpi}$, but were first detectable from $28 \mathrm{dpi}$ and the antibody titer increased continuously. In the serum samples of hamsters inoculated at 8 weeks old, neutralizing antibodies were detected from 7 dpi and increased gradually, as those of the 4-week-old hamsters.

\subsection{Viral load in organs and blood clots}

To examine the PUUV distribution in the body, organ and blood samples were collected at 3 to $70 \mathrm{dpi}$, and the PUUV load in various organs and blood clots was measured by quantitative real-time PCR. For the samples of hamsters inoculated at 4 weeks old, viral RNA was detected in various organs and blood clots (Fig. 2 and Table 1). In lung samples, viral RNA was detected from $3 \mathrm{dpi}$ and peaked at $14 \mathrm{dpi}$ with values ranging from $1.3 \times 10^{4}$ to 8.7 $\times 10^{4}$ viral RNA copies/ng of GAPDH mRNA. Then the viral load declined gradually, but the viral RNA was maintained to 70 dpi. In kidney and spleen samples, high levels of viral RNA were also detected. Viral RNA was detected from 7 dpi and was maintained until the end of the observation period with values ranging from $9.5 \times 10^{-1}$ to $2.4 \times 10^{3}$ and $4.3 \times 10^{0}$ to $9.9 \times$ $10^{2}$ viral RNA copies/ng of GAPDH mRNA from kidney and spleen samples, respectively. In liver samples, the viral RNA became positive from 7 dpi and the viral load peaked at $14 \mathrm{dpi}$ with values ranging from $7.0 \times 10^{1}$ to $1.8 \times 10^{3}$ viral RNA copies/ng of GAPDH mRNA. Then the viral RNA levels declined quickly and became undetectable from 55 dpi. In heart samples, the viral RNA was detectable from 7 dpi and was maintained through 70 dpi with 
values ranging from $3.5 \times 10^{-1}$ to $5.5 \times 10^{1}$ viral RNA copies/ng of GAPDH mRNA, but the RNA levels were lower compared to those detected in other organs such as the lung, kidney, and spleen. In brain samples, the viral RNA was detected from 7 dpi and observed through 70 days, and showed a double-peaked pattern at 28 and 55 dpi with high levels around $1.0 \times 10^{4}$ viral RNA copies/ng of GAPDH mRNA. In blood clot samples, viral RNA was detected occasionally from 3 to $70 \mathrm{dpi}$, with values ranging from $2.5 \times 10^{-4}$ to $6.3 \times 10^{1}$ viral RNA copies/ng of GAPDH mRNA.

For the organ and blood samples of hamsters inoculated at 8 weeks old, the highest value of viral RNA was also detected in lung samples (Fig. 3 and Table 2). The viral RNA in lungs was detected from 7 to $42 \mathrm{dpi}$, ranging from $3.0 \times 10^{-1}$ to $8.9 \times 10^{3}$ viral RNA copies/ng of GAPDH mRNA, and then became undetectable from 56 dpi. In kidney, spleen, liver, and heart samples, viral RNA was detected occasionally from 7 and 56 dpi. In brain samples, no viral RNA was detected at any time point of infection. No viral RNA was detected from saliva, urine, or feces (data not shown).

\subsection{Antigen detection from lungs}

Lung samples were analyzed for the presence of viral N. To estimate the cutoff value of N-ELISA, 20 samples of lung from uninfected hamsters were tested. A cutoff value of 0.6 was determined as the mean absorbance value of 20 uninfected hamster samples plus three times the standard deviation (data not shown).

Lungs of hamsters inoculated at 4 weeks old were tested (Table 1). Only three of 20 samples showed absorbance values greater than 0.6; one sample was taken at 7 dpi and two samples at 14 dpi. The viral RNA levels of these N-positive samples were also high, with values ranging from $4.8 \times 10^{4}$ to $8.7 \times 10^{4}$ copies/ng of GAPDH mRNA. Therefore, the results of N-ELISA and quantitative real-time PCR corresponded well with each other. All 
other samples were negative by N-ELISA.

Lungs of hamsters inoculated at 8 weeks old were also tested, but all samples were negative for hantavirus $\mathrm{N}$ (Table 2).

\subsection{Pathological studies}

To reveal whether PUUV infection in hamsters causes pathological changes, and to determine cell tropism of viral antigens in organs, we examined the organs of PUUV-infected hamsters through pathological and histochemical analyses (Figs. 4-6 and Table 3).

Lung, kidney, spleen, liver, heart, brain, and adrenal gland were stained with hematoxylin and eosin for morphological study and with monoclonal antibody against hantaviral $\mathrm{N}$ to determine the presence of viral proteins.

Histopathological changes and hantavirus-specific staining were observed in some organs of hamsters inoculated at 4 weeks old. At 7 dpi, thickened alveolar wall was observed with very slight cellular infiltration of neutrophils and mononuclear cells (Fig. 4A). Upon immunohistochemical analysis, viral antigens were localized in those pulmonary cells (Fig. 4B). At 14 dpi, cellular infiltrations including multinuclear giant cells were detected in the alveolar area (Fig. 4C), and hantavirus antigen-positive cells were detected in these cells (Fig. 4D). At 28 and 56 dpi, no detectable histopathological changes and viral antigens were observed (Fig. 4E and F).

The kidneys of infected hamsters showed no clear histopathological changes. By immunohistochemical analysis, viral antigens were found in cells of the kidney medulla from 7 and 14 dpi (Fig. 5A and B). At 28 and 56 dpi, tubular epithelial cells and vascular endothelial cells of the renal pelvis were PUUV-positive (Fig. 5C and D).

In the adrenal glands, very slight vacuolar degeneration was observed in hantavirus antigen-positive cells in the adrenal cortex of the hamster at 7 dpi (Fig. 5E). At 14 dpi, slight 
inflammatory infiltration and virus antigen-positive cells were observed in the adrenal cortex (Fig. 5F). In adrenal glands at 28 and 56 dpi, degenerated cells were present and virus antigens were positive in the nuclei (data not shown).

At 7 dpi, histopathological changes were absent in the brain of infected hamsters. Also, hantavirus-specific staining was not observed in the brain. At 14 dpi, slight cell infiltrations with mononuclear cells and microglia were detected in the cortex of the cerebellum from one of the infected hamsters (Fig. 6A). Upon immunohistochemical analysis, virus antigen was observed in degenerated Purkinje cells at 14 dpi (Fig. 6B). At 28 dpi, slight cell infiltrations were seen in the third ventricle (Fig. 6C), and ependymal cells were PUUV- positive (Fig. 6D).

In addition to these organs, we also examined the spleens, livers, hearts, and cerebrums. No histopathological changes or hantavirus-specific staining were found (data not shown).

In contrast to the organs of hamsters inoculated at 4 weeks old, those of hamsters inoculated at 8 weeks old showed no histopathological changes or hantavirus specific staining (data not shown). 


\section{Discussion}

Although many researchers have reported experimental infections using various animal species with several hantaviruses, few reliable animal models of hantavirus infection exist. As a disease model for HCPS, a previous study showed that ANDV, a causative agent of HCPS in South America, causes a lethal disease in Syrian hamsters, of which the characteristics were very similar to HCPS in humans (Hooper et al., 2001). Maporal virus, a South American hantavirus, also causes a disease in Syrian hamsters that resembles HCPS closely (Milazzo et al., 2002). In addition, Cynomolgus macaques infected with PUUV, which causes a mild form of HFRS, has been reported as a disease model for HFRS (Klingström et al., 2002). In contrast to the animal models of human infection, an animal model of persistent infection that mimics the infection of natural rodent reservoirs had not been established. To date, newborn animals infected with hantavirus experimentally were reported to show persistent infection (Araki et al., 2003; Compton et al., 2004; Kariwa et al., 1996; Tanishita et al., 1986). However, maternal antibodies are believed to protect newborn animals from vertical transmission (Bernshtein et al., 1999; Borucki et al., 2000; Botten et al., 2002; Gavrilovskaya et al., 1990; Taruishi et al., 2008). Therefore, in nature, hantavirus infection is believed to occur in adults. Herein, we report that PUUV in Syrian hamsters inoculated as subadults shows persistent infection that is similar to that in its principal rodent host, the bank vole $(M$. glareolus).

In this study, we demonstrated that the organs of Syrian hamsters infected with PUUV at 4 weeks old contained a high amount of viral RNA that was maintained for at least 70 days. Most organs showed the peak of viral RNA copies from 7 to 14 dpi followed by a gradual decline. In addition, the viral RNA was maintained for at least 70 days despite the existence of neutralizing antibodies. These data correspond well with the results of previous studies conducted on experimentally infected host rodents (Botten et al., 2000; Hutchinson et al., 
1998). Therefore, our findings suggest that PUUV in Syrian hamsters establishes persistent infection similar to that in the natural rodent reservoir.

For most individuals, the highest titer of viral RNA was detected in lung samples. In particular, lung samples at 7 and 14 dpi from hamsters inoculated at 4 weeks old contained high copies of viral RNA. By N-ELISA, the antigens were also detected in these samples. These data suggest that the lung is a suitable site for viral replication. Additionally, kidney, spleen, and brain samples also showed high copy numbers of RNA. This virus distribution pattern resembles the results of studies on experimental infection with PUUV in M. glareolus (Yanagihara et al., 1985), natural infection with PUUV in M. glareolus (Korva et al., 2009), and other hantaviruses in their rodent hosts (Botten et al., 2000; Compton et al., 2004; Daud et al., 2007; Hutchinson et al., 1998; Kariwa et al., 1996; Tanishita et al., 1986). In adrenal gland samples from hamsters inoculated at 4 weeks old, viral antigens were observed from 7 to 56 dpi. Other studies have also reported high titers of virus and high prevalence of virus in adrenal glands (Hinson et al., 2004; Hutchinson et al., 1998). These results indicate that the adrenal gland may be one of the sites of replication and maintenance of hantavirus. In liver samples from hamsters inoculated at 4 weeks old, the titer of viral RNA at 7 and 14 dpi was high like in other organs, but viral RNA was transient unlike in other organs. Similar results were also obtained in several studies (Compton et al., 2004; Fulhorst et al., 2002; Hutchinson et al., 1998). Viral replication in the liver may more suppressed than in other organs.

Unlike the natural rodent host (Gavrilovskaya et al., 1990; Hardestam et al., 2008; Yanagihara et al., 1985), the viral RNA was not detected from saliva, urine, or feces samples of hamsters with PUUV. The amount of excreted PUUV from infected hamsters may be extremely low level. Another possible explanation is that the virus shedding pattern of PUUV-infected hamster may be intermittent or transient like SNV-infected deer mouse (Botten et al., 2000). To clarify this point, further study focusing on virus shedding is needed. 
It is generally believed that hantavirus infection in the natural hosts does not show apparent clinical manifestations. In this study, hamsters with PUUV showed no signs of clinical illness or loss of body weight. When hamsters were inoculated at 4 weeks old, very slight inflammatory reactions were observed in the lung, cerebellum, and adrenal gland in the acute phase of infection. These histopathological findings were different from the results of M. glareolus infected with PUUV, which showed that organs contained viral antigens without pathological change (Yanagihara et al., 1985); however, endothelial hyperplasia in vascular walls and lymphohistiocytic infiltration has been observed in M. glareolus experimentally infected with PUUV (Gavrilovskaya et al., 1990). Recent study also showed that BCCV in experimentally infected in Sigmodon hispidus, the principal host of BCCV, causes pneumonitis and the severity of pneumonitis is dependent on inoculated dose as well as infection period (Billings et al., 2010). Furthermore, some reports indicated that New World hantavirus in wild rodents causes pathological changes in tissues (Lyubsky et al., 1996; Netski et al., 1999). Certain level of pathlogical change may occur in hantavirus infection in the natural host. Because histopathological studies on natural rodent hosts infected with hantavirus are scarce, analyzing in greater detail the pathology and cell tropism of hantavirus in wild rodents is necessary.

In this study, the modes of infection differed between hamsters inoculated at 4 and 8 weeks old. Infection at 4 weeks old showed high titers of viral RNA and continued through at least $70 \mathrm{dpi}$, whereas infection at 8 weeks old was transient. IgM of hamsters inoculated at 4 weeks old was induced persistently, but that of the 8-week-old hamsters was quite low. These data suggest that 4-week-old hamsters may allow more PUUV replication to stimulate the host immune system persistently compared to 8-week-old hamsters. Hamsters infected with other viruses also showed different modes of infection between 4 and 8 weeks old (Morrey et al., 2004; Xiao et al., 2001). Therefore, the age at infection is probably an important factor in 
determining the mode of viral infection. At 4 weeks old, the host immune system of hamsters may still be immature, causing persistent infection in those hamsters.

In this study, Syrian hamsters infected with PUUV at 4 weeks old showed persistent infection despite the presence of neutralizing antibodies, without any clinical symptoms, which is quite similar to the infection in natural host rodents. These data indicated that hamsters could be a suitable animal model for studying hantavirus infection in the reservoir host. This animal model would be a useful tool to clarify the mechanism of persistent infection in the natural rodent reservoir. In addition, because there is few appropriate laboratory animal model for PUUV infection, this model could also be useful for in vivo evaluations of vaccines and antiviral therapies for the treatment of PUUV infection. 
T. Sanada

\section{Acknowledgements}

This work was supported financially by Grants-in-Aid for Scientific Research (16405034 and 17255009) from the Japanese Ministry of Education, Culture, Sports, Science and Technology, and by a Health and Labour Sciences Research Grant on Emerging and Re-emerging Infectious Diseases from the Japanese Ministry of Health, Labour and Welfare. This work was also supported by the global COE Program for Zoonosis Control. (Hokkaido University). 


\section{References}

Araki, K., Yoshimatsu, K., Lee, B.H., Kariwa, H., Takashima, I., Arikawa, J., 2003. Hantavirus-specific CD8(+)-T-cell responses in newborn mice persistently infected with Hantaan virus. J. Virol. 77 (15), 8408-8417.

Bernshtein, A.D., Apekina, N.S., Mikhailova, T.V., Myasnikov, Y.A., Khlyap, L.A., Korotkov, Y.S., Gavrilovskaya, I.N., 1999. Dynamics of Puumala hantavirus infection in naturally infected bank voles (Clethrinomys glareolus). Arch. Virol. 144 (12), 2415-2428.

Bi, Z., Formenty, P.B., Roth, C.E., 2008. Hantavirus infection: a review and global update. J. Infect. Dev. Ctries. 2 (1), 3-23.

Billings, A.N., Rollin, P.E., Milazzo, M.L., Molina, C.P., Eyzaguirre, E.J., Livingstone, W., Ksiazek, T.G., Fulhorst, C.F., 2010. Pathology of Black Creek Canal virus infection in juvenile hispid cotton rats (Sigmodon hispidus). Vector Borne Zoonotic Dis. 10 (6), 621-628.

Borucki, M.K., Boone, J.D., Rowe, J.E., Bohlman, M.C., Kuhn, E.A., DeBaca, R., St Jeor, S.C., 2000. Role of maternal antibody in natural infection of Peromyscus maniculatus with Sin Nombre virus. J. Virol. 74 (5), 2426-2429.

Botten, J., Mirowsky, K., Kusewitt, D., Bharadwaj, M., Yee, J., Ricci, R., Feddersen, R.M., Hjelle, B., 2000. Experimental infection model for Sin Nombre hantavirus in the deer mouse (Peromyscus maniculatus). Proc. Natl. Acad. Sci. U. S. A. 97 (19), 10578-10583.

Botten, J., Mirowsky, K., Ye, C., Gottlieb, K., Saavedra, M., Ponce, L., Hjelle, B., 2002. Shedding and intracage transmission of Sin Nombre hantavirus in the deer mouse (Peromyscus maniculatus) model. J. Virol. 76 (15), 7587-7594.

Compton, S.R., Jacoby, R.O., Paturzo, F.X., Smith, A.L., 2004. Persistent Seoul virus infection in Lewis rats. Arch. Virol. 149 (7), 1325-1339.

Daud, N.H., Kariwa, H., Tanikawa, Y., Nakamura, I., Seto, T., Miyashita, D., Yoshii, K., Nakauchi, M., Yoshimatsu, K., Arikawa, J., Takashima, I., 2007. Mode of infection of 
Hokkaido virus (Genus Hantavirus) among grey red-backed voles, Myodes rufocanus, in Hokkaido, Japan. Microbiol. Immunol. 51 (11), 1081-1090.

Fulhorst, C.F., Milazzo, M.L., Duno, G., Salas, R.A., 2002. Experimental infection of the Sigmodon alstoni cotton rat with Cano Delgadito virus, a South American hantavirus. Am. J. Trop. Med. Hyg. 67 (1), 107-111.

Gavrilovskaya, I.N., Apekina, N.S., Bernshtein, A.D., Demina, V.T., Okulova, N.M., Myasnikov, Y.A., Chumakov, M.P., 1990. Pathogenesis of hemorrhagic fever with renal syndrome virus infection and mode of horizontal transmission of hantavirus in bank voles. Arch. Virol. (Suppl 1) 57-62.

Hardestam, J., Karlsson, M., Falk, K.I., Olsson, G., Klingstrom, J., Lundkvist, A., 2008. Puumala hantavirus excretion kinetics in bank voles (Myodes glareolus). Emerg. Infect. Dis. $14(8), 1209-1215$.

Hinson, E.R., Shone, S.M., Zink, M.C., Glass, G.E., Klein, S.L., 2004. Wounding: the primary mode of Seoul virus transmission among male Norway rats. Am. J. Trop. Med. Hyg. 70 (3), 310-317.

Hooper, J.W., Larsen, T., Custer, D.M., Schmaljohn, C.S., 2001. A lethal disease model for hantavirus pulmonary syndrome. Virology. 289 (1), 6-14.

Hutchinson, K.L., Rollin, P.E., Peters, C.J., 1998. Pathogenesis of a North American hantavirus, Black Creek Canal virus, in experimentally infected Sigmodon hispidus. Am. J. Trop. Med. Hyg. 59 (1), 58-65.

Jonsson, C.B., Figueiredo, L.T., Vapalahti, O., 2010. A global perspective on hantavirus ecology, epidemiology, and disease. Clin. Microbiol. Rev. 23 (2), 412-441.

Kanerva, M., Mustonen, J., Vaheri, A., 1998. Pathogenesis of puumala and other hantavirus infections. Rev. Med. Virol. 8 (2), 67-86.

Kariwa, H., Yoshizumi, S., Arikawa, J., Yoshimatsu, K., Takahashi, K., Takashima, I., 
Hashimoto, N., 1995. Evidence for the existence of Puumala-related virus among Clethrionomys rufocanus in Hokkaido, Japan. Am. J. Trop. Med. Hyg. 53 (2), 222-227.

Kariwa, H., Kimura, M., Yoshizumi, S., Arikawa, J., Yoshimatsu, K., Takashima, I., Hashimoto, N., 1996. Modes of Seoul virus infections: persistency in newborn rats and transiency in adult rats. Arch. Virol. 141 (12), 2327-2338.

Klingström, J., Plyusnin, A., Vaheri, A., Lundkvist, A., 2002. Wild-type Puumala hantavirus infection induces cytokines, C-reactive protein, creatinine, and nitric oxide in cynomolgus macaques. J. Virol. 76 (1), 444-449.

Korva, M., Duh, D., Saksida, A., Trilar, T., Avsic-Zupanc, T., 2009. The hantaviral load in tissues of naturally infected rodents. Microbes Infect. 11 (3), 344-351.

Lee, H.W., Lee, P.W., Baek, L.J., Song, C.K., Seong, I.W., 1981. Intraspecific transmission of Hantaan virus, etiologic agent of Korean hemorrhagic fever, in the rodent Apodemus agrarius. Am. J. Trop. Med. Hyg. 30 (5), 1106-1112.

Lyubsky, S., Gavrilovskaya, I., Luft, B., Mackow, E., 1996. Histopathology of Peromyscus leucopus naturally infected with pathogenic NY-1 hantaviruses: pathologic markers of HPS viral infection in mice. Lab. Invest. 74 (3), 627-633.

Milazzo, M.L., Eyzaguirre, E.J., Molina, C.P., Fulhorst, C.F., 2002. Maporal viral infection in the Syrian golden hamster: a model of hantavirus pulmonary syndrome. J. Infect. Dis. 186 (10), 1390-1395.

Morrey, J.D., Day, C.W., Julander, J.G., Olsen, A.L., Sidwell, R.W., Cheney, C.D., Blatt, L.M., 2004. Modeling hamsters for evaluating West Nile virus therapies. Antiviral Res. 63 (1), 41-50.

Muranyi, W., Bahr, U., Zeier, M., van der Woude, F.J., 2005. Hantavirus infection. J. Am. Soc. Nephrol. 16 (12), 3669-3679.

Netski, D., Thran, B.H., St Jeor, S.C., 1999. Sin Nombre virus pathogenesis in 
Peromyscus maniculatus. J. Virol. 73 (1), 585-591.

Plyusnin, A., Vapalahti, O., Vaheri, A., 1996. Hantaviruses: genome structure, expression and evolution. J. Gen. Virol. 77 (Pt 11), 2677-2687.

Tanishita, O., Takahashi, Y., Okuno, Y., Tamura, M., Asada, H., Dantas, J.R., Jr., Yamanouchi, T., Domae, K., Kurata, T., Yamanishi, K., 1986. Persistent infection of rats with haemorrhagic fever with renal syndrome virus and their antibody responses. J. Gen. Virol. 67 (Pt 12), 2819-2824.

Taruishi, M., Yoshimatsu, K., Hatsuse, R., Okumura, M., Nakamura, I., Arikawa, J., 2008. Lack of vertical transmission of Hantaan virus from persistently infected dam to progeny in laboratory mice. Arch. Virol. 153 (8), 1605-1609.

Vapalahti, O., Mustonen, J., Lundkvist, A., Henttonen, H., Plyusnin, A., Vaheri, A., 2003. Hantavirus infections in Europe. Lancet Infect. Dis. 3 (10), 653-661.

Xiao, S.Y., Zhang, H., Guzman, H., Tesh, R.B., 2001. Experimental yellow fever virus infection in the Golden hamster (Mesocricetus auratus). II. Pathology. J. Infect. Dis. 183 (10), $1437-1444$

Yanagihara, R., Amyx, H.L., Gajdusek, D.C., 1985. Experimental infection with Puumala virus, the etiologic agent of nephropathia epidemica, in bank voles (Clethrionomys glareolus). J. Virol. 55 (1), 34-38.

Yoshimatsu, K., Arikawa, J., Tamura, M., Yoshida, R., Lundkvist, A., Niklasson, B., Kariwa, H., Azuma, I., 1996. Characterization of the nucleocapsid protein of Hantaan virus strain 76-118 using monoclonal antibodies. J. Gen. Virol. 77 (Pt 4), 695-704. 


\section{Figure legends}

Fig. 1. Antibody responses in hamsters infected by the PUUV Sotkamo strain. Kinetics of $\operatorname{IgG}(\mathrm{A})$ and $\operatorname{IgM}(\mathrm{B})$ responses in hamsters inoculated at 4 and 8 weeks old as determined by ELISA. Kinetics of IgG responses were also determined by IFA (C). Neutralizing antibody titers of serum samples were evaluated by the $80 \%$ focus reduction method (D). Error bars represent the standard deviation.

Fig. 2. Viral loads of hamsters inoculated at 4 weeks old. The viral load in each organ was measured by quantitative real-time PCR and is expressed as the mean of all positive organs at each time point. The number of positive organs/organs tested is expressed above the bar for each time point. Error bars represent the standard deviation.

Fig. 3. Viral loads of hamsters inoculated at 8 weeks old. The viral load in each organ was measured by quantitative real-time PCR and is expressed as the mean of all positive organs at each time point. The number of positive organs/organs tested is expressed above the bar for each time point. Error bars represent the standard deviation.

Fig. 4. Morphologic and immunohistochemical examination of lungs from hamsters inoculated at 4 weeks old. Bar, $50 \mu \mathrm{m}$. (A) Very slight cellular proliferation of neutrophils and mononuclear cells were observed in the interstitium at 7 dpi. (B) Immunohistochemical staining with hantavirus-specific antibody revealed virus antigen-positive cells (arrows) in the cellular proliferation sites in the alveolar area at 7 dpi. (C) Cellular infiltrations including macrophages and multinuclear giant cells (arrow, inset, asterisk) in the alveolar area at $14 \mathrm{dpi}$. (D) PUUV-positive cells (arrows) in the alveolar area at 14 dpi. (E, F) No histopathological 
change and viral antigen were observed at 28 dpi (E) and 56 dpi (F).

Fig. 5. Morphologic and immunohistochemical examination of kidneys and adrenal glands from hamsters inoculated at 4 weeks old. Bar, $50 \mu \mathrm{m}$. (A, B) PUUV-positive cells were detected in the kidney medulla of the hamsters at 7 dpi (A) and 14 dpi (B). (C, D) PUUV-positive cells were tubular epithelial cells and vascular endothelial cells of the renal pelvis at 28 dpi (C) and 56 dpi (D). (E) At 7 dpi, very slight vacuolar degeneration cells (arrows) present in the adrenal cortex were positive for virus antigen (inset). (F) Slight inflammatory infiltrations (arrows) and virus antigen-positive cells (inset) in the adrenal cortex at 14 dpi.

Fig. 6. Morphologic and immunohistochemical examination of brains from hamsters inoculated at 4 weeks old. Bar, $50 \mu \mathrm{m}$. (A) Mild cell infiltrations with mononuclear cells and microglia in the cortex of cerebellum at 14 dpi (arrows, inset) from one hamster. (B) Immunohistochemical staining with anti-hantavirus-specific antibody revealed virus antigen-positive cells in the Purkinje cell layer (inset). (C) Slight cell infiltrations around the third ventricle at 28 dpi (arrows). (D) Virus antigen-positive cells included ependymal cells at 28 dpi (inset). 
T. Sanada

The English in this document has been checked by at least two professional editors, both native speakers of English. For a certificate, please see:

http://www.textcheck.com/certificate/OwFXoC 
Table 1. Viral load in tissues and antibody responses in sera of PUUV infected hamsters (4 weeks o

\begin{tabular}{|c|c|c|c|c|c|c|c|c|c|c|c|c|c|}
\hline \multirow{2}{*}{$\begin{array}{l}\text { Days post } \\
\text { inoculation }\end{array}$} & \multirow[t]{2}{*}{ No. } & \multirow{2}{*}{$\begin{array}{c}\text { Antigen } \\
\text { N-ELISA* }\end{array}$} & \multicolumn{7}{|c|}{ Viral load (Real-time PCR: viral RNA copies/ ng of GAPDH mRNA) } & \multicolumn{2}{|c|}{$\begin{array}{l}\text { Antibody } \\
\text { (IgG) }\end{array}$} & \multirow{2}{*}{$\begin{array}{l}\text { Antibody } \\
\text { (IgM) } \\
\text { IgM-ELISA }\end{array}$} & \multirow{2}{*}{$\begin{array}{c}\begin{array}{c}\text { Neutralizing } \\
\text { antibody }\end{array} \\
\text { FRNT }\end{array}$} \\
\hline & & & Lung & Kindey & Spleen & Liver & Heart & Brain & Blood clot & IgG-ELISA & IFA & & \\
\hline \multirow[t]{3}{*}{3} & 1 & 0.409 & $3.8 \times 10^{-1}$ & - & - & - & - & - & - & 0 & $<16$ & 0.031 & $<20$ \\
\hline & 2 & 0.4055 & $1.9 \times 10^{1}$ & - & - & - & - & - & $2.8 \times 10^{-1}$ & 0 & $<16$ & 0.0265 & $<20$ \\
\hline & 3 & 0.3965 & $1.7 \times 10^{0}$ & - & - & - & - & - & - & 0 & $<16$ & 0.0095 & 20 \\
\hline \multirow[t]{3}{*}{7} & 4 & 0.435 & $2.1 \times 10^{0}$ & - & - & - & - & - & - & 0 & $<16$ & 0.01 & $<20$ \\
\hline & 5 & 0.3705 & $1.9 \times 10^{2}$ & $9.5 \times 10^{-1}$ & $4.3 \times 10^{0}$ & $6.1 \times 10^{0}$ & - & - & $3.4 \times 10^{-1}$ & 0 & $<16$ & 0.027 & $<20$ \\
\hline & 6 & 0.936 & $4.8 \times 10^{4}$ & $1.1 \times 10^{3}$ & $6.3 \times 10^{2}$ & $1.0 \times 10^{3}$ & $2.4 \times 101$ & $5.8 \times 10^{-1}$ & $3.9 \times 10^{1}$ & 0.071 & $<16$ & 0.008 & $<20$ \\
\hline \multirow[t]{3}{*}{14} & 7 & 0.391 & $1.3 \times 10^{4}$ & $5.6 \times 10^{2}$ & $1.6 \times 10^{2}$ & $7.0 \times 10^{1}$ & $5.8 \times 10^{0}$ & $9.4 \times 10^{1}$ & - & 0 & 1024 & 0.4925 & $<20$ \\
\hline & 8 & 2.4625 & $8.7 \times 10^{4}$ & $1.0 \times 10^{3}$ & $9.4 \times 10^{2}$ & $1.2 \times 10^{3}$ & $5.5 \times 10^{1}$ & $7.8 \times 10^{1}$ & $3.4 \times 10^{1}$ & 0.3855 & 16 & 0.084 & $<20$ \\
\hline & 9 & 2.3485 & $8.1 \times 10^{4}$ & $8.2 \times 10^{2}$ & $9.9 \times 10^{2}$ & $1.8 \times 10^{3}$ & $1.7 \times 10^{1}$ & $1.1 \times 10^{2}$ & $6.3 \times 10^{1}$ & 0.7145 & 128 & 0.0865 & $<20$ \\
\hline \multirow[t]{3}{*}{28} & 10 & 0.5475 & $1.3 \times 10^{2}$ & $1.6 \times 10^{1}$ & $2.2 \times 10^{2}$ & $1.1 \times 10^{0}$ & $8.5 \times 10^{-1}$ & $2.4 \times 10^{1}$ & - & 2.211 & 32768 & 0.2995 & $<20$ \\
\hline & 11 & 0.3635 & $3.2 \times 10^{2}$ & $6.7 \times 10^{2}$ & $1.4 \times 10^{2}$ & $1.0 \times 10^{1}$ & $1.2 \times 10^{1}$ & $9.2 \times 10^{3}$ & $1.1 \times 10^{2}$ & 0.4935 & 16384 & 0.343 & $<20$ \\
\hline & 12 & 0.5165 & $9.4 \times 10^{2}$ & $8.4 \times 10^{1}$ & $3.7 \times 10^{2}$ & $1.8 \times 10^{1}$ & $3.2 \times 10^{1}$ & $3.1 \times 10^{2}$ & - & 0.659 & 16384 & 0.3545 & 160 \\
\hline \multirow[t]{3}{*}{42} & 13 & 0.513 & $1.8 \times 10^{2}$ & $1.8 \times 10^{2}$ & $2.7 \times 10^{1}$ & $2.0 \times 10^{-1}$ & $5.9 \times 10^{0}$ & $1.9 \times 10^{1}$ & - & 2.652 & 16384 & 0.3795 & 80 \\
\hline & 14 & 0.4 & $1.2 \times 10^{2}$ & $2.4 \times 10^{3}$ & $1.6 \times 10^{2}$ & - & $7.8 \times 10^{0}$ & $1.9 \times 10^{0}$ & - & 2.6265 & 16384 & 0.2625 & 20 \\
\hline & 15 & 0.3505 & $2.7 \times 10^{2}$ & $2.2 \times 10^{1}$ & $5.6 \times 10^{1}$ & - & $3.2 \times 10^{0}$ & $2.5 \times 10^{1}$ & - & 2.354 & 16384 & 0.3795 & 80 \\
\hline \multirow[t]{3}{*}{55} & 16 & 0.3565 & $6.3 \times 10^{2}$ & $2.6 \times 10^{2}$ & $1.7 \times 10^{2}$ & - & $2.1 \times 10^{1}$ & $1.2 \times 10^{4}$ & - & 1.665 & 32768 & 0.5855 & 160 \\
\hline & 17 & 0.503 & $9.7 \times 10^{1}$ & $1.6 \times 10^{1}$ & $5.1 \times 10^{1}$ & - & $3.2 \times 10^{0}$ & $6.4 \times 10^{1}$ & $2.5 \times 10^{-4}$ & 1.47 & 16384 & 0.2605 & 40 \\
\hline & 18 & 0.3885 & $4.5 \times 10^{2}$ & $1.9 \times 10^{2}$ & $7.1 \times 10^{1}$ & - & $6.7 \times 10^{0}$ & $2.0 \times 10^{1}$ & - & 1.2705 & 32768 & 0.4435 & 160 \\
\hline \multirow[t]{2}{*}{70} & 19 & 0.511 & - & $1.4 \times 10^{0}$ & - & - & - & - & - & 1.583 & 512 & 0.045 & 160 \\
\hline & 20 & 0.4375 & $7.8 \times 10^{1}$ & $3.1 \times 10^{2}$ & $6.6 \times 10^{1}$ & - & $3.5 \times 10^{-1}$ & $4.0 \times 10^{0}$ & $1.6 \times 10^{-2}$ & 1.4185 & 16384 & 0.203 & 80 \\
\hline
\end{tabular}

-, Under the detectable level.

$*$ Cut off value $=0.6$ 
Table 2. Viral load in tissues and antibody responses in sera of PUUV infected hamsters (8 weeks o.

\begin{tabular}{|c|c|c|c|c|c|c|c|c|c|c|c|c|}
\hline \multirow{2}{*}{$\begin{array}{l}\text { Days post } \\
\text { inoculation }\end{array}$} & \multirow[t]{2}{*}{ No. } & \multirow{2}{*}{$\begin{array}{c}\text { Antigen } \\
\text { N-ELISA* }\end{array}$} & \multicolumn{6}{|c|}{ Viral load (Real-time PCR: viral RNA copies/ng of GAPDH mRNA) } & \multicolumn{2}{|c|}{$\begin{array}{l}\text { Antibody } \\
\text { (IgG) }\end{array}$} & \multirow{2}{*}{$\begin{array}{c}\begin{array}{c}\text { Antibody } \\
(\text { IgM) }\end{array} \\
\text { IgM-ELISA }\end{array}$} & \multirow{2}{*}{$\begin{array}{c}\begin{array}{c}\text { Neutralizing } \\
\text { antibody }\end{array} \\
\text { FRNT }\end{array}$} \\
\hline & & & Lung & Kindey & Spleen & Liver & Heart & Brain & IgG-ELISA & IFA & & \\
\hline \multirow[t]{3}{*}{3} & 1 & 0.3605 & - & - & - & - & - & - & 0.5945 & $<16$ & 0 & $<20$ \\
\hline & 2 & 0.4185 & - & - & - & - & - & - & 0 & $<16$ & 0.001 & $<20$ \\
\hline & 3 & 0.4 & - & - & - & - & - & - & 0.102 & $<16$ & 0 & $<20$ \\
\hline \multirow[t]{4}{*}{7} & 4 & 0.4115 & $4.0 \times 10^{1}$ & - & - & $1.2 \times 10^{0}$ & - & - & 0 & $<16$ & 0.013 & $<20$ \\
\hline & 5 & 0.479 & $8.9 \times 10^{3}$ & $1.0 \times 10^{2}$ & $2.8 \times 10^{2}$ & $1.9 \times 10^{2}$ & $1.0 \times 10^{1}$ & - & 0 & $<16$ & 0.0325 & $<20$ \\
\hline & 6 & 0.398 & $9.3 \times 10^{2}$ & N.D. & N.D. & N.D. & N.D. & N.D. & 0 & $<16$ & 0.0265 & 20 \\
\hline & 7 & 0.295 & $5.7 \times 10^{1}$ & - & $6.0 \times 10^{0}$ & $1.3 \times 10^{0}$ & - & - & 0.205 & $<16$ & 0.0115 & 20 \\
\hline \multirow[t]{5}{*}{14} & 8 & N.D. & N.D. & N.D. & N.D. & N.D. & N.D. & N.D. & 0.591 & 128 & 0.128 & 40 \\
\hline & 9 & N.D. & N.D. & N.D. & N.D. & N.D. & N.D. & N.D. & 0.626 & 256 & 0.097 & 20 \\
\hline & 10 & 0.427 & $2.5 \times 10^{3}$ & $4.9 \times 10^{1}$ & $7.1 \times 10^{1}$ & $2.0 \times 10^{1}$ & $1.6 \times 10^{0}$ & - & 0.3775 & $<16$ & 0.031 & 20 \\
\hline & 11 & 0.3475 & - & $1.3 \times 10^{-1}$ & - & - & - & - & 0.1685 & $<16$ & 0.03 & $<20$ \\
\hline & 12 & 0.398 & $1.4 \times 10^{2}$ & $4.3 \times 10^{-1}$ & - & - & - & - & 1.7535 & 1024 & 0.1215 & 20 \\
\hline \multirow[t]{5}{*}{28} & 13 & N.D. & N.D. & N.D. & N.D. & N.D. & N.D. & N.D. & 1.7935 & 8192 & 0.121 & 20 \\
\hline & 14 & 0.53 & N.D. & N.D. & N.D. & N.D. & N.D. & N.D. & 1.9575 & 512 & 0.027 & 20 \\
\hline & 15 & 0.4605 & $3.0 \times 10^{-1}$ & - & - & - & - & - & 1.551 & 256 & 0.0305 & 20 \\
\hline & 16 & 0.2315 & $9.9 \times 10^{1}$ & - & - & - & - & - & 2.1175 & 512 & 0.062 & 20 \\
\hline & 17 & 0.3535 & $3.4 \times 10^{1}$ & - & - & - & - & - & 0.2285 & 128 & 0.1035 & 20 \\
\hline \multirow[t]{3}{*}{42} & 18 & 0.404 & $1.5 \times 10^{2}$ & $1.9 \times 10^{1}$ & $1.1 \times 10^{1}$ & - & $6.4 \times 10^{-1}$ & - & 1.6105 & 512 & 0.2905 & 80 \\
\hline & 19 & 0.394 & - & - & - & - & - & - & 1.9955 & 256 & 0.0155 & 80 \\
\hline & 20 & 0.3935 & - & - & - & - & - & - & 0.6655 & 64 & 0.027 & 20 \\
\hline \multirow[t]{3}{*}{56} & 21 & 0.4315 & - & - & $4.5 \times 10^{0}$ & - & - & - & 2.2365 & 256 & 0.0255 & 160 \\
\hline & 22 & 0.3965 & - & - & - & - & - & - & 1.6765 & 256 & 0.0285 & 80 \\
\hline & 23 & 0.3075 & - & - & - & - & - & - & 2.3095 & 256 & 0.0515 & 80 \\
\hline \multirow[t]{3}{*}{70} & 24 & 0.348 & - & - & - & - & - & - & 0.531 & 256 & 0.0145 & 160 \\
\hline & 25 & 0.4345 & - & - & - & - & - & - & 1.1515 & 256 & 0.0375 & 160 \\
\hline & 26 & 0.404 & - & - & - & - & - & - & 0.943 & 512 & 0.019 & 160 \\
\hline
\end{tabular}

- , Under the detectable level.

$*$ Cut off value $=0.6$ 
Table 3. Detection of PUUV antigen from tissues of infected hamsters by immunohistochemical analysis

\begin{tabular}{llccccc}
\hline \multirow{2}{*}{ Age } & Tissue & \multicolumn{5}{c}{ No.of virus-positive/no.of tested animals } \\
& & $7 \mathrm{dpi}$ & $14 \mathrm{dpi}$ & $28 \mathrm{dpi}$ & $56 \mathrm{dpi}$ & mock \\
\hline 4 & Lung & $1 / 1$ & $2 / 2$ & $0 / 2$ & $0 / 2$ & $0 / 1$ \\
& Kidney & $1 / 1$ & $2 / 2$ & $2 / 2$ & $2 / 2$ & $0 / 1$ \\
& Spleen & $0 / 1$ & $0 / 2$ & $0 / 2$ & $0 / 2$ & $0 / 1$ \\
& Liver & $0 / 1$ & $0 / 2$ & $0 / 2$ & $0 / 2$ & $0 / 1$ \\
& Heart & $0 / 1$ & $0 / 2$ & $0 / 2$ & $0 / 2$ & $0 / 1$ \\
Cerebrum & $0 / 1$ & $0 / 2$ & $0 / 2$ & $0 / 2$ & $0 / 1$ \\
Cerebellum & $0 / 1$ & $1 / 2$ & $1 / 2$ & $0 / 2$ & $0 / 1$ \\
& Adrenal gland & $1 / 1$ & $2 / 2$ & $1 / 2$ & $1 / 2$ & $\mathrm{NE}$ \\
8 & & & & $\mathrm{NE}$ & $0 / 1$ \\
& Lung & $0 / 1$ & $0 / 2$ & $0 / 2$ & $\mathrm{NE}$ & $0 / 1$ \\
& Kidney & $0 / 1$ & $0 / 2$ & $0 / 2$ & $\mathrm{NE}$ & $0 / 1$ \\
& Spleen & $0 / 1$ & $0 / 2$ & $0 / 2$ & $\mathrm{NE}$ & $0 / 1$ \\
& Liver & $0 / 1$ & $0 / 2$ & $0 / 2$ & $\mathrm{NE}$ & $0 / 1$ \\
Heart & $0 / 1$ & $0 / 2$ & $0 / 2$ & $\mathrm{NE}$ & $0 / 1$ \\
& Cerebrum & $0 / 1$ & $0 / 2$ & $0 / 2$ & $\mathrm{NE}$ & $0 / 1$ \\
& Cerebellum & $\mathrm{NE}$ & $0 / 1$ & $0 / 1$ & $\mathrm{NE}$ & $\mathrm{NE}$ \\
\hline Adrenal gland & $\mathrm{NE}$ & $\mathrm{NE}$ & $\mathrm{NE}$ & &
\end{tabular}

NE, not examined 
A

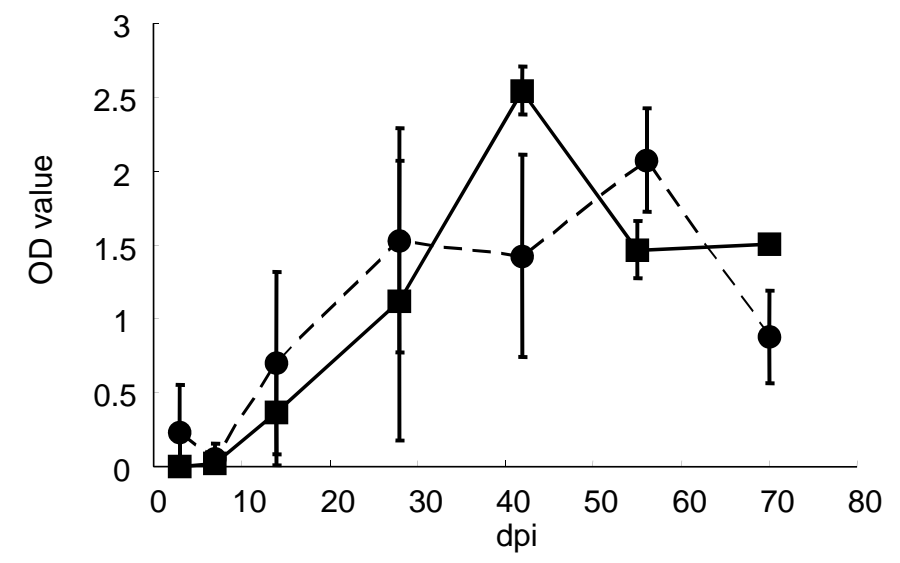

C

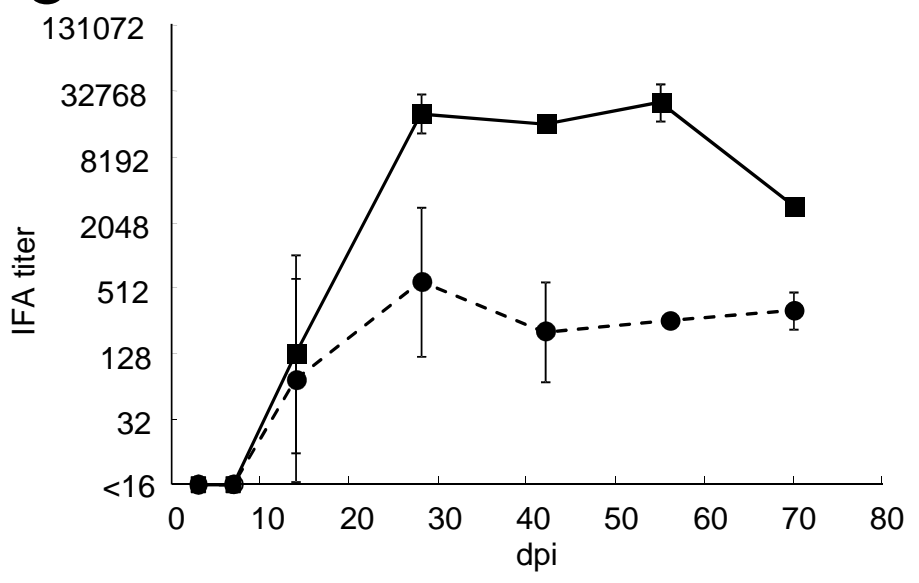

B

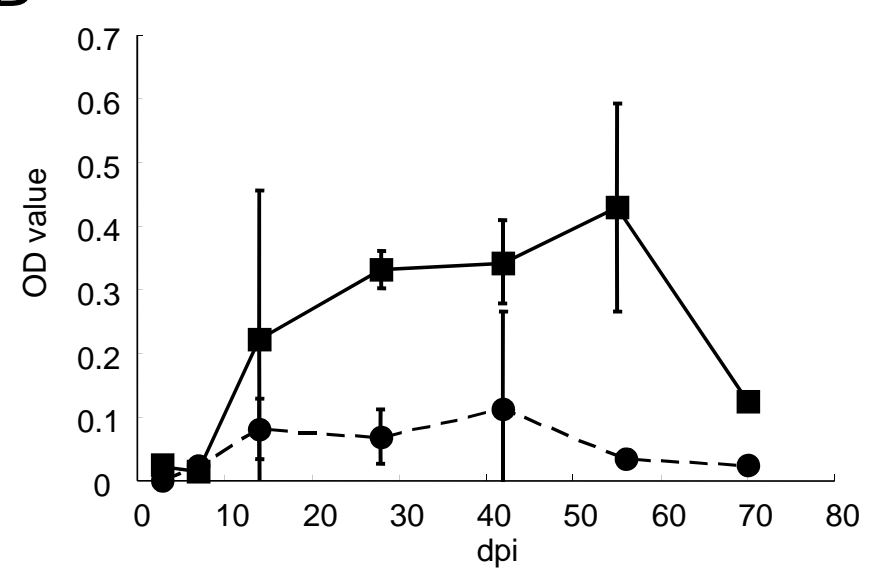

D

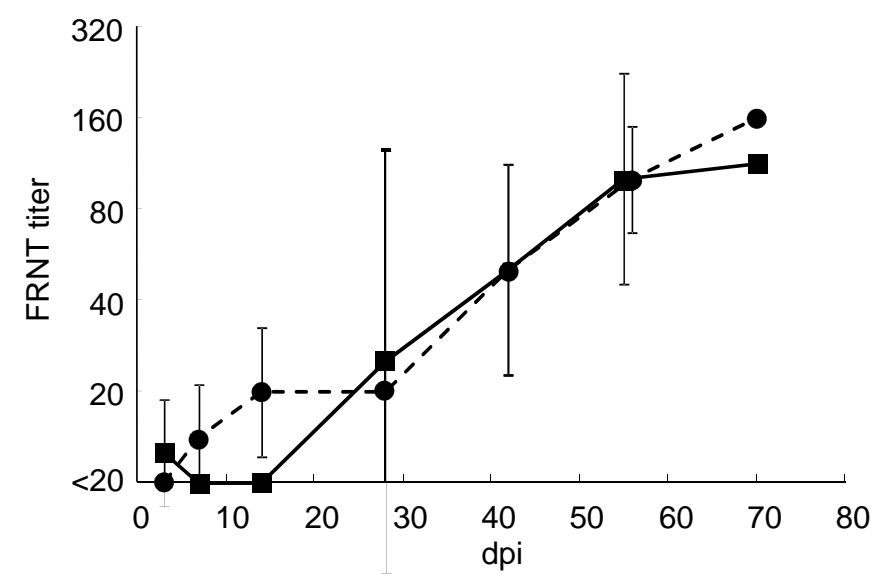

Fig. 1. Sanada, et al. 

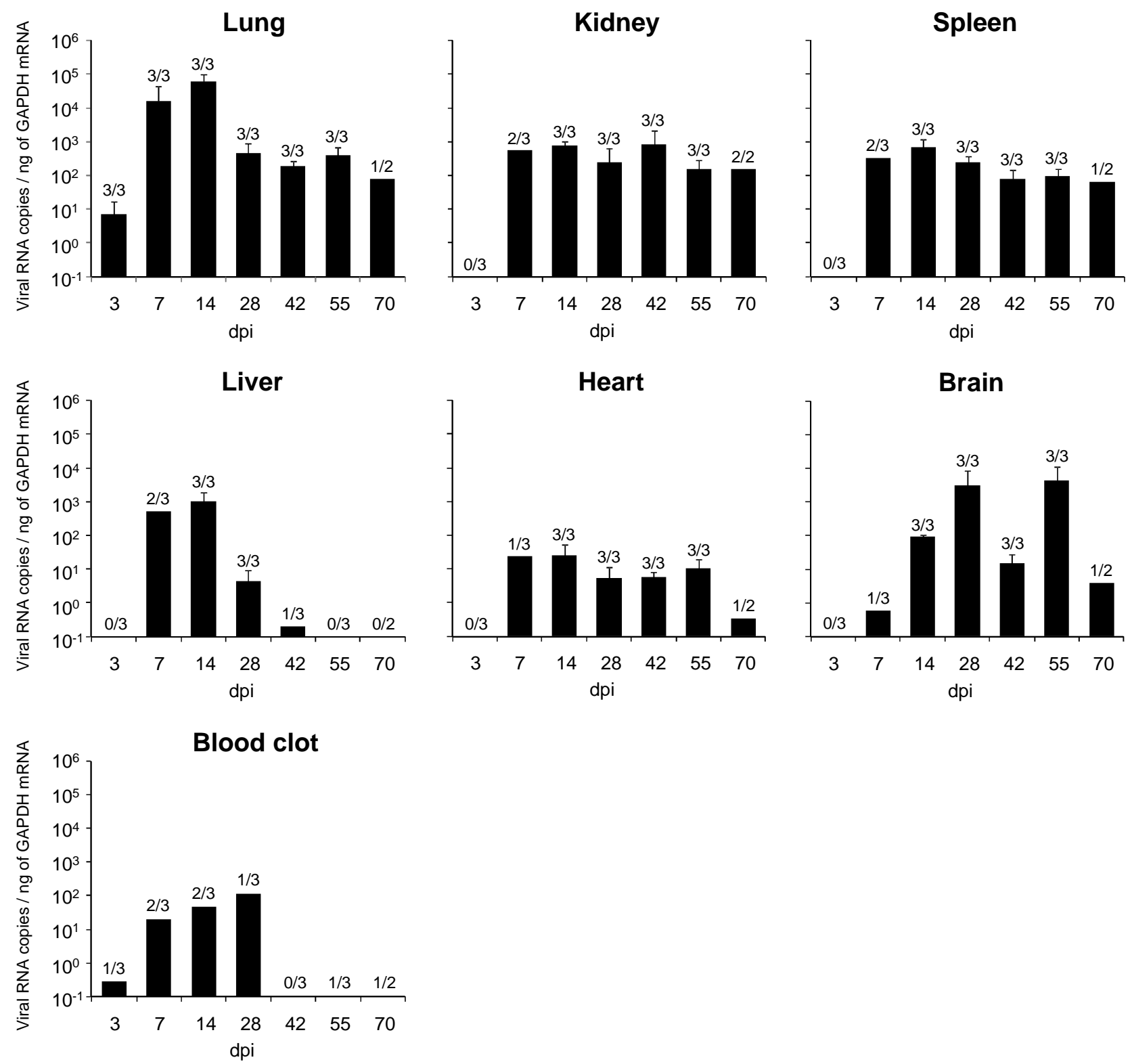

Fig. 2. Sanada, et al. 

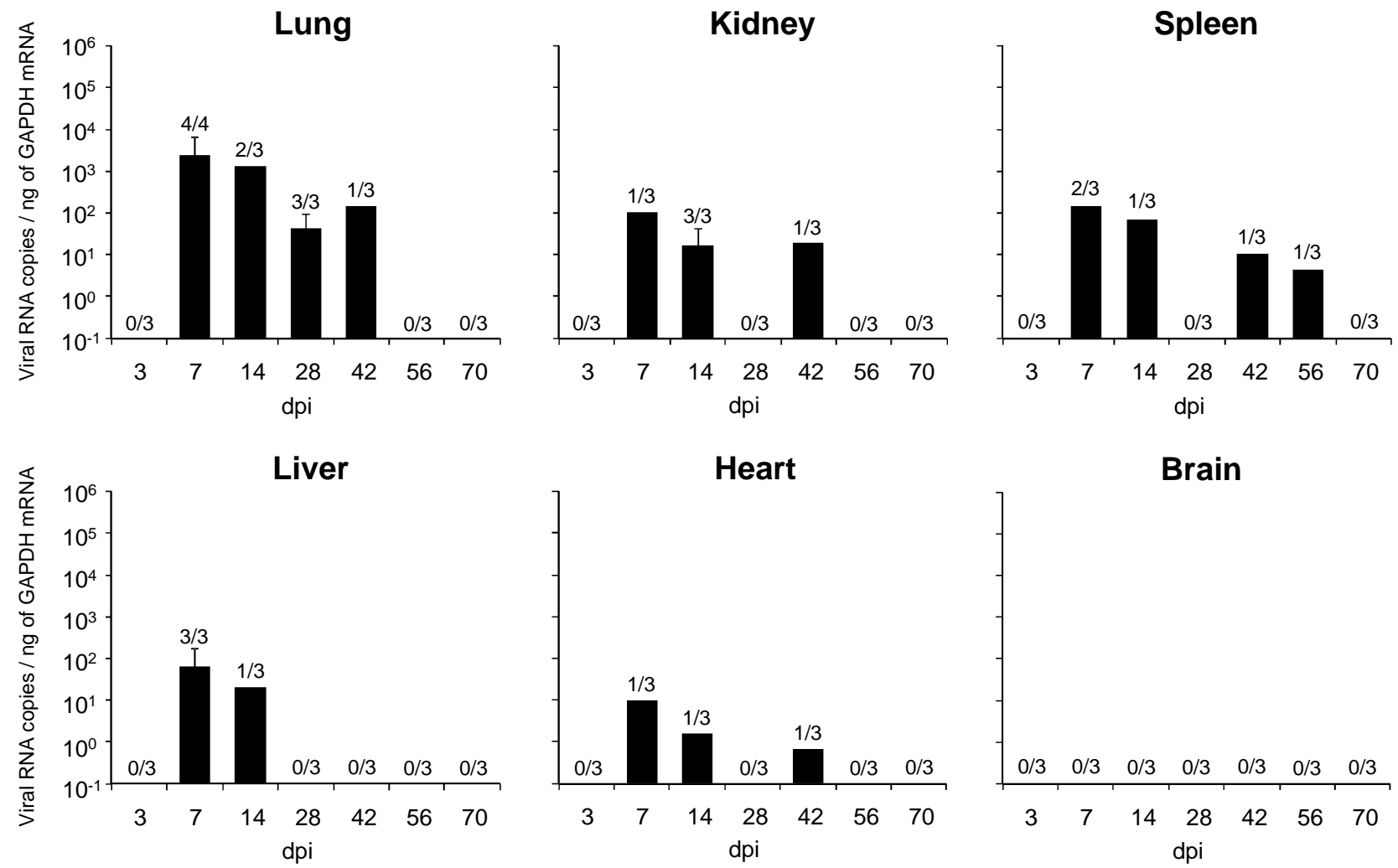

Fig. 3. Sanada, et al. 
勇然

א.

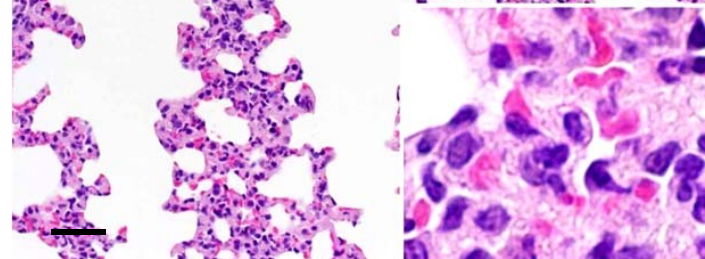
.
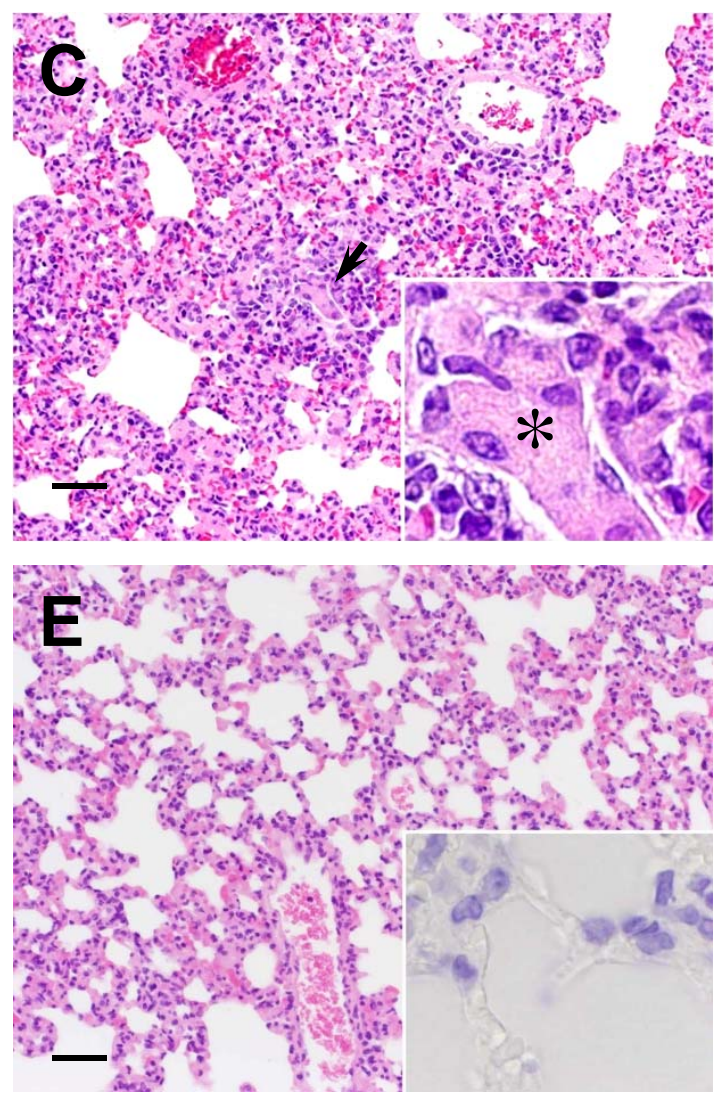

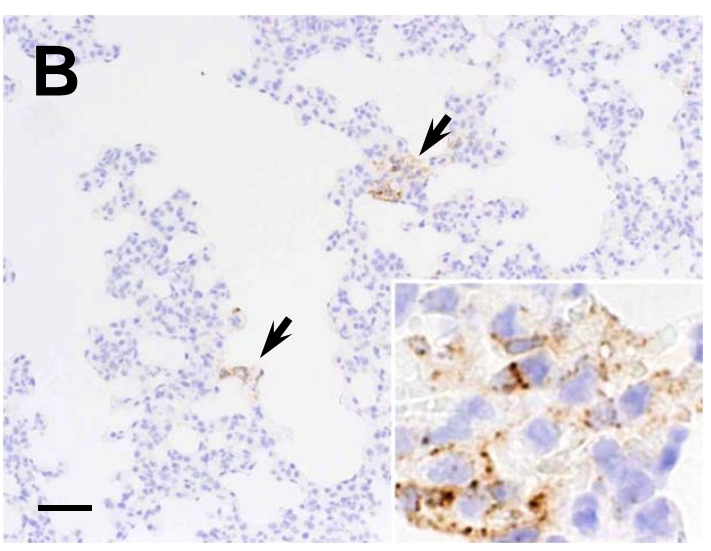

D
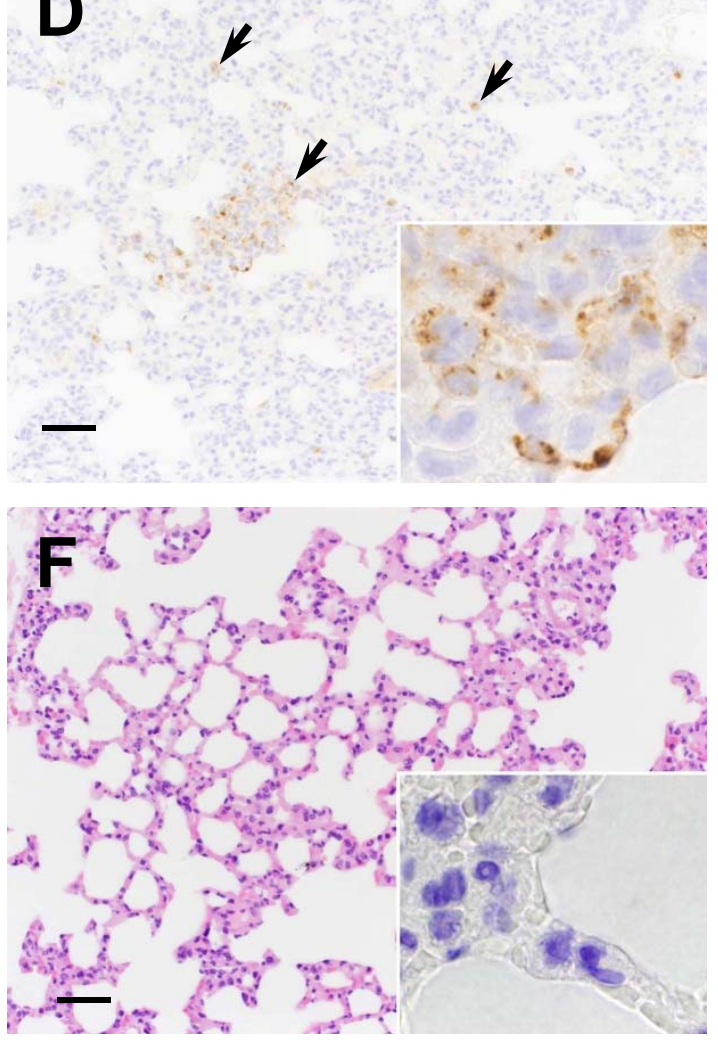

Fig. 4. Sanada, et al. 

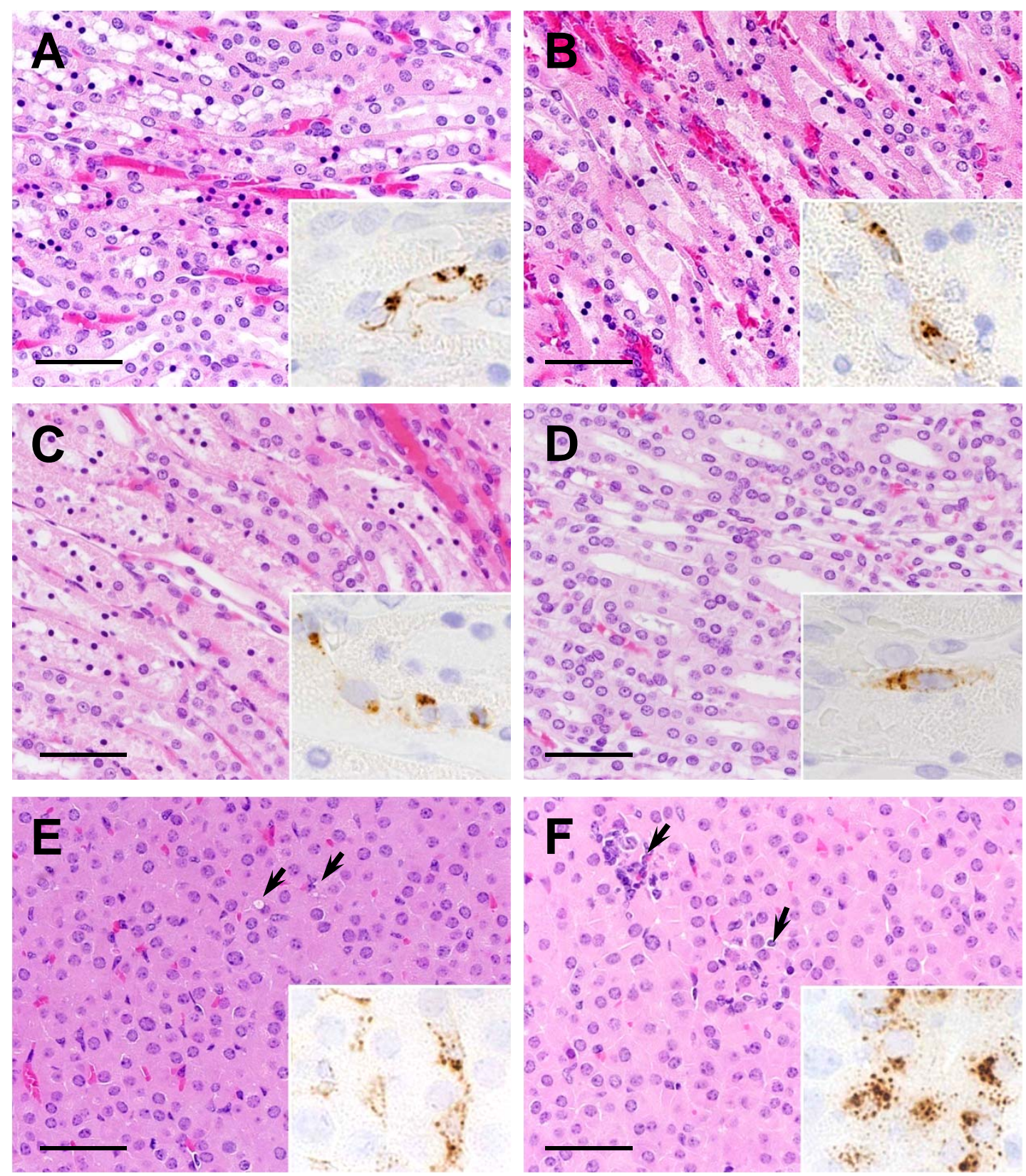

Fig. 5. Sanada, et al. 

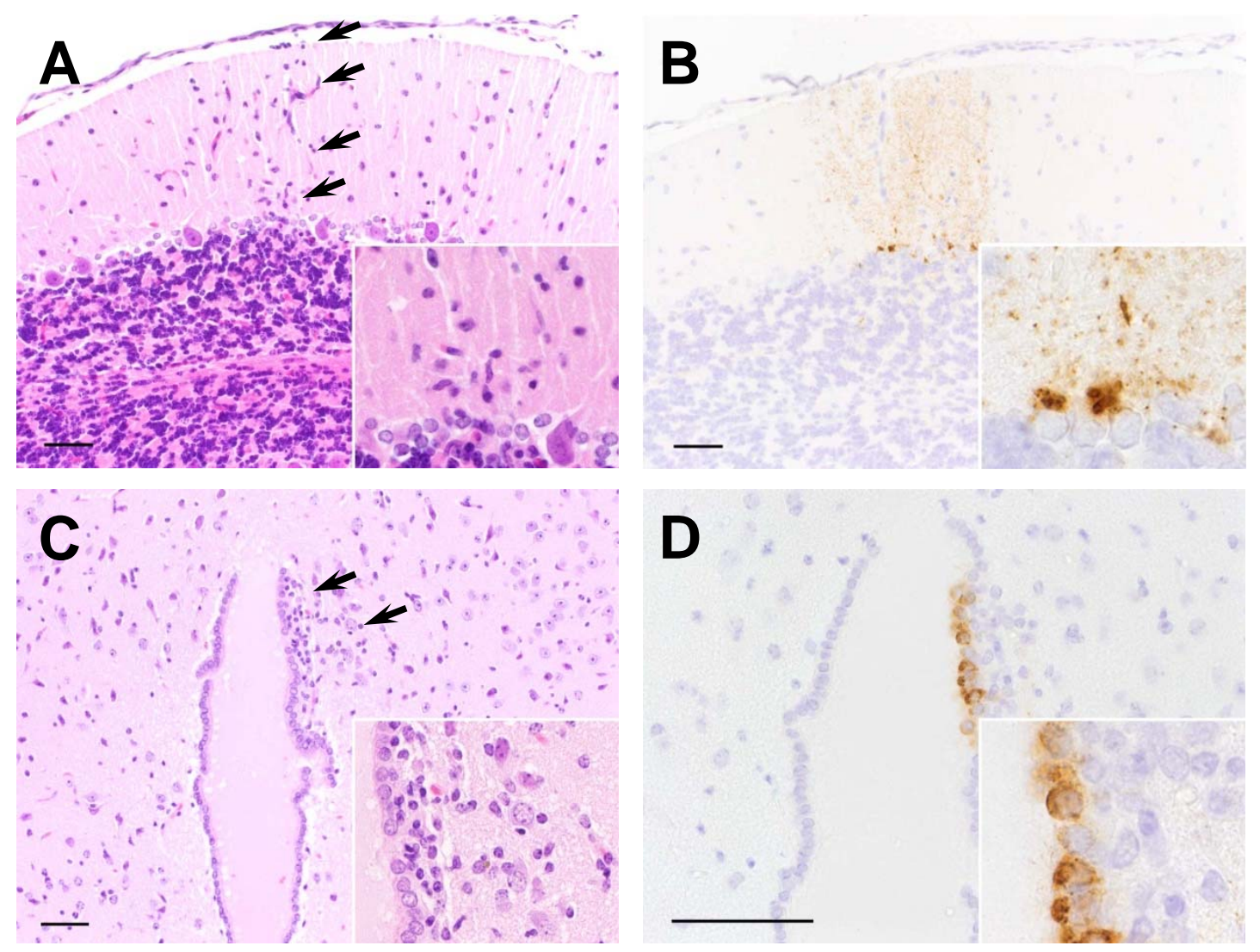

Fig. 6. Sanada, et al. 